Volume 9. No. 4, April 2021

International Journal of Emerging Trends in Engineering Research

Available Online at http://www.warse.org/IJETER/static/pdf/file/ijeter30942021.pdf

https://doi.org/10.30534/ijeter/2021/30942021

\title{
Statistical Analysis of Renewable Energy Resources of Pakistan
}

\author{
Abubakar Siddique ${ }^{1}$, M. Waqar Hassan ${ }^{2}$, Waseem Aslam ${ }^{3}$, M.Nadeem Aslam ${ }^{4}$, M.Kaleem Aslam ${ }^{4}$, \\ Maham Fatima ${ }^{5}$ \\ ${ }^{1}$ Department of Electrical Engineering, Khwaja Fareed University of Engineering \&Technology (KFUEIT), \\ Rahim Yar Khan, Pakistan. \\ ${ }^{2}$ Department of Electrical Engineering, Superior university Lahore, 54000, Pakistan. \\ ${ }^{3}$ Department of Electrical Engineering, University of Sargodha (UOS), Sargodha, Pakistan. \\ ${ }^{4}$ Department of Electrical Engineering, NFC (IET), Multan, Pakistan. \\ ${ }^{5}$ Department of Electrical \& Computer Engineering, COMSATs University Islamabad, Sahiwal Campus.
}

\begin{abstract}
Despite of being one of the richest countries in energy resources Pakistan is facing a huge short fall of electrical energy as energy demand is increasing rapidly but increase in generation capability is much slow. Currently Pakistan is using a huge amount of non-renewable energy resources to produce electricity which is not only expensive but also affecting the environment due to by-products of this process. This is a common trend throughout the world to use renewable resources of energy as it is economical and nature friendly. This paper gives an overview of currently used methods for power generation in Pakistan and a gives a brief detail on how and in which areas of the country power generation can be done using renewable resources of energy. Cost of installing the system is also one of the most important factors but will not be discussed here because purpose of this paper is only to help the reader to know about different renewable resources of energy.

Numerous types of wind turbines i.e. Bonus 300/33.4, NEG/Micon 1000/60, Vestas 600/42 and Whisper 0.9/2.13 have been statistically analyzed, for the energy they could ideally produce, under the same atmospheric conditions. The coasts of Karachi are proposed to be among the ideal, most suitable sites, for the erection of wind farms, in Pakistan. Wind-Data for the year 2003 (previously acquired through anemometers) is processed in "MATLAB" to implement the "Curve Fitting techniques" adjusting the " $\mathrm{k}$ " and "c", the shape and scale parameters, respectively, of the "Weibull Distribution" so that the refined Wind-Data curves resemble the ones made by the Raw-Data, minus the anomalies. Furthermore, the refined data is then extracted to be populated in the spreadsheets for mathematical/statistical calculations.
\end{abstract}

Key words: Renewable energy, wind power, solar PV, ocean energy, bio energy, hydro power, geothermal energy, Probability Density Function, Matlab, Weibull distribution, Approximation algorithms, Statistical Analysis.

\section{INTRODUCTION}

Pakistan is sixth most populous country in south Asia with population more than 200 million with $70 \%$ of the total population living in rural areas. Pakistan has a 1046-kilometer-long costal area. Electricity is the basic need of every person in the present era. With the advancement in technology large area of Pakistan had been electrified but still around 30 million people are living without electricity. Although not every person is provided with electricity but still there is not enough generation in Pakistan for the 24-hour constant supply. There is almost 8 hours of load shedding every day. Due to this short fall of electricity not only the daily life of people had been disturbed but also there is a negative impact on the economy of Pakistan.

There is not only the need of installation of new power plants but also a great work is required in the field of energy to explore new methods of power generation as all the method in present time are those which uses the non-renewable resources

of energy. If a comparison is done with other countries Pakistan is far behind other countries in term of use of renewable sources of energy. There had been a lot of development in India and Bangladesh in the field of renewable resources of energy. India is generating $14 \%$ of its total installed capacity by renewable resources, while Bangladesh has also expanded the network of power generation to smaller level. Denmark is on the top of the list by generating $39.1 \%$ of the total energy through renewable resources and aims to extend it to $100 \%$ by 2050 .

The purpose of this paper is to explore different renewable resources of energy which can be used for the generation of electrical power and in which areas of Pakistan this method can be used.

\section{Power Generation and Demand in Pakistan}

Power generation capability of Pakistan is around 22,000 MW which no doubt has increased with passage of time but still it is much less as compared to energy demand in Pakistan. Figure 1 shows the power generation capability of Pakistan in different years [1]-[2]. 


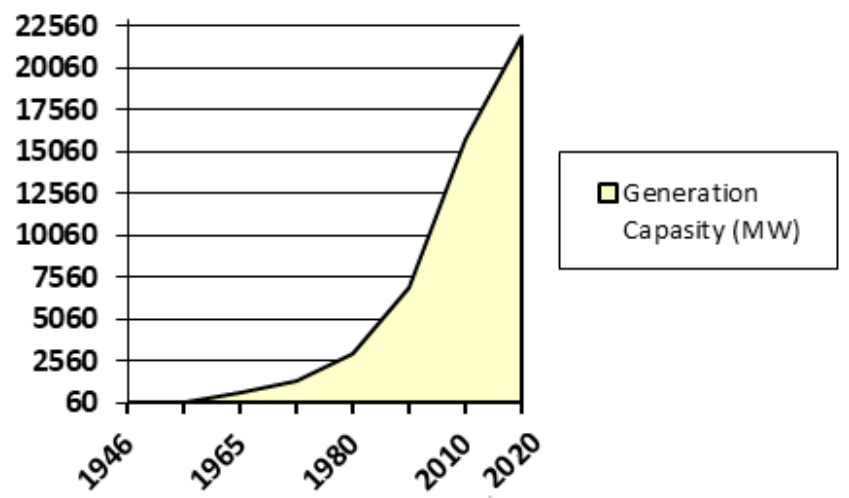

Figure 1: Power Generation Capacity

Maximum power demand in last year is around 20,966 MW with a shortfall of $6000 \mathrm{MW}$ has been recorded. These statistics are enough to tell that how much needed is the installation of new power plants. Figure 2 gives an overview of the participation of each source in the power generation [3]. Around $29 \%$ of the total capacity is through hydropower and only $3 \%$ by other renewable sources of energy, which tells us how much we are dependent on the non-renewable resources of energy to meet out daily demand of electricity.

\section{Renewable Energy Sources in Pakistan}

Renewable resources of energy are those which are naturally replenished on the human scale, these have some advantages over the non-renewable resources such that while harvesting energy from these resources there is no cost of fuel nor they produce hazardous by-products such as $\mathrm{CO}_{2}$ so these are knows as green sources of energy. Along with the advantages there are some disadvantages such that we can-not control the supply of fuel in most of the cases and the installing cost is much high. Renewable resources which are used for harvesting electrical energy are hydropower, ocean energy, solar energy, wind energy geothermal energy and bio energy.

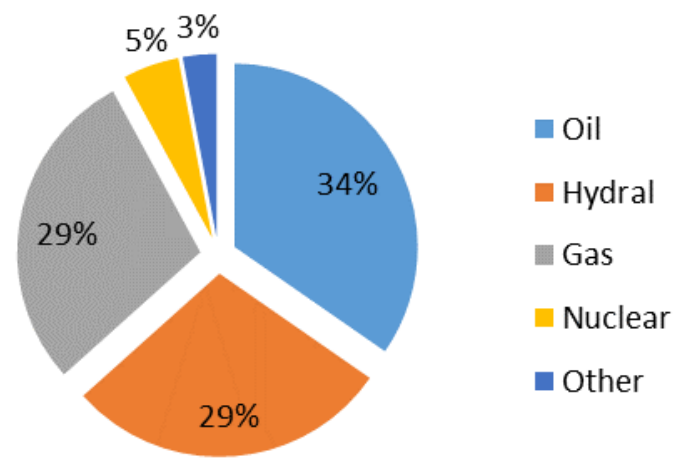

Figure 2: Source wise Power Generation

\subsection{Renewable Energy Resources in Pakistan}

Renewable resources of energy are those which are naturally replenished on the human scale, these have some advantages over the non-renewable resources such that while harvesting energy from these resources there is no cost of fuel nor they produce hazardous by-products such as $\mathrm{CO}_{2}$ so these are knows as green sources of energy. Along with the advantages there are some disadvantages such that we can-not control the supply of fuel in most of the cases and the installing cost is much high. Renewable resources which are used for harvesting electrical energy are hydropower, ocean energy, solar energy, wind energy geothermal energy and bio energy.

\section{A. Hydropower}

Hydropower is a renewable source of energy which can be used to obtain electrical power by energy stored in the flow of water, this flow might be natural as such in rivers in the hilly areas or it can be obtained by storing water dams. Pakistan hydra sources has a potential of around 50,000 MW but currently installed system has only ability to harvest 6611 MW of energy which is about $29 \%$ of the total installed capacity [2]. Around 26 projects are under construction with the capacity of $10,000 \mathrm{MW}$ and around 80 hydropower projects are proposed having a capacity of 30,000 MW [3].

Northern areas of Pakistan are remotely populated and energy demand in those areas is less as compared to other areas of the country. There are a large number of waterfalls and small streams which can also produce a good amount of electricity, according to a survey around $300 \mathrm{MW}$ can be generated from such streams. Pakistan also had one of the biggest irrigation systems in the world. Figure 3 represents a schematic diagram of this system.

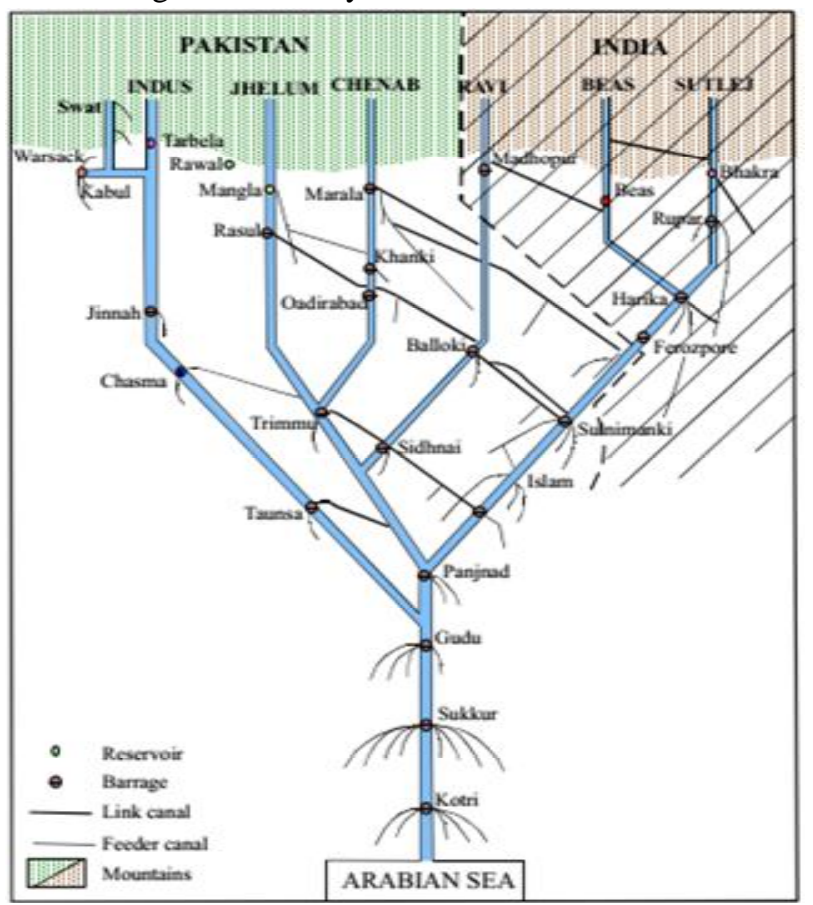

Figure 3: Schematic representation of irrigation system of Pakistan

Ministry of Science and Technology has installed 290 micro-grids in FATA and northern areas with a capacity of 3-50 KW per unit which adds up to the total capacity up to 3.5 MW [4]. Installation of more micro hydropower plants are 
in process and these plants are fulfilling the needs of residents to the domestic level.

This irrigation system has a great potential for hydropower projects. Small hydro power projects can be installed on some off the canals. Table 1 shows how much power can be generated from some of the canals in Punjab province [5].

TABLE 1: Proposed sites and their power potential

\begin{tabular}{|c|c|c|c|c|c|}
\hline $\begin{array}{l}\text { Sr. } \\
\text { No. }\end{array}$ & $\begin{array}{c}\text { Name of } \\
\text { Canal }\end{array}$ & Location & $\begin{array}{c}\text { Discharg } \\
\text { e (ft3/s) }\end{array}$ & $\begin{array}{c}\text { Fall } \\
(\mathbf{f t})\end{array}$ & MW \\
\hline 1 & $\begin{array}{c}\text { Baloki- } \\
\text { Sulamanki } \\
\text { L-1 }\end{array}$ & $\begin{array}{c}\text { RD1062 } \\
50\end{array}$ & 12500 & $\begin{array}{c}10.6 \\
4\end{array}$ & 10 \\
\hline 2 & $\begin{array}{c}\text { Baloki- } \\
\text { Sulamanki } \\
\text { L-1 }\end{array}$ & $\begin{array}{c}\text { RD3343 } \\
0\end{array}$ & 9000 & $\begin{array}{c}17.8 \\
6\end{array}$ & $\begin{array}{c}10.7 \\
2\end{array}$ \\
\hline 3 & $\begin{array}{c}\text { Chenab } \\
\text { Jhelum } \\
\text { Link }\end{array}$ & $\begin{array}{c}\text { RD3166 } \\
22\end{array}$ & 13527 & $\begin{array}{c}41.7 \\
0\end{array}$ & 40 \\
\hline 4 & $\begin{array}{c}\text { Upper } \\
\text { Chanab }\end{array}$ & RD0 & 16500 & 8.83 & 9.70 \\
\hline 5 & $\begin{array}{c}\text { TP Link } \\
\text { Canal }\end{array}$ & $\begin{array}{c}\text { RD1830 } \\
00\end{array}$ & 12000 & 3.00 & $\begin{array}{c}12.2 \\
8\end{array}$ \\
\hline
\end{tabular}

\section{B. Ocean Energy}

Ocean energy relates to all kind of renewable energy which can be obtained from the sea. Ocean energy can be in form of mechanical energy i.e. waves and tides, or it can be in form of thermal energy from the sun. Electrical power from the sea can be obtained from water waves caused by air flow above the water surface or from the tides in ocean caused by gravitational pull of moon and sun. Wave and tidal energy is converted into electrical energy by using different devices as listed by EMEC [6].

Figure 4 shows per meter energy flux of the water wave throughout the world with the encircled portion representing sea area occupied by Pakistan. Pakistan sea water has an energy flux of 10-15 KW/m [7]. On 19 March 2015 UNO has accepted Pakistan claim for extension in sea boundary from 200 nautical miles to 350 nautical miles. In result of this acceptance Pakistan offshore territory expanded to 290,000 sq kilometer from 240,000 sq. kilometer [8]. Considering these statics, it is clear that how much of electricity can be produced by water waves.

As described before tides are formed due to the gravitational force of sun and moon. Tides can be used for harnessing electrical energy due to change in water level. This method has predictable output as compared to wave energy. Pakistan experience two high and two low tides in a single day so compiling up to 730 tides throughout the year. Tidal data for some coastal areas of Pakistan is given in the Table 2. All of the seven locations can be used for generation of electric power; taking into account the statistical data of Port Qasim as it is the one with highest flood time and tidal height around 43,015 KWh per tide and annual of $9.03 \mathrm{GWh}$ considering plant factor of $30 \%$ can be generated from this single location [9].

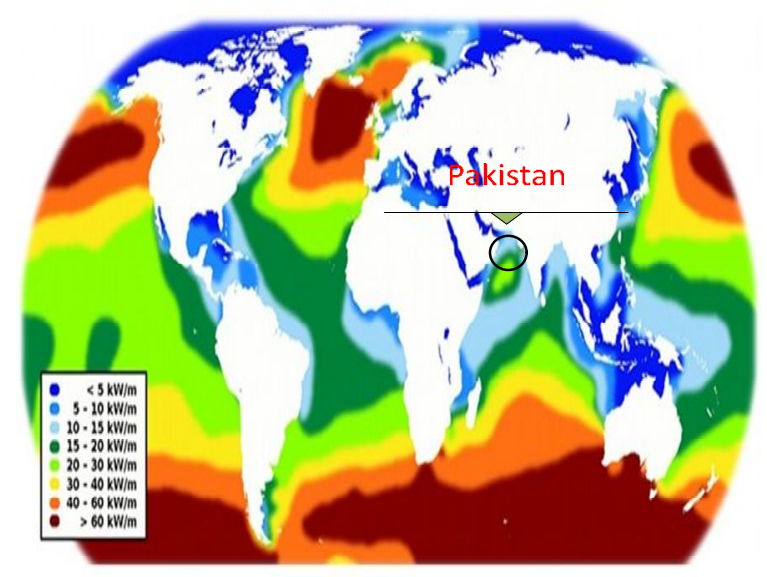

Figure 4: Energy flux of water waves in world.

TABLE 2: Pakistan annual Tidal Statics at different stations

\begin{tabular}{|c|c|c|c|c|}
\hline Station Location & $\begin{array}{c}\text { Avg. } \\
\text { Flood } \\
\text { Time }\end{array}$ & $\begin{array}{c}\text { Avg. Ebb } \\
\text { Time }\end{array}$ & $\begin{array}{c}\text { Avg. } \\
\text { Tide } \\
(\mathrm{m})\end{array}$ & $\begin{array}{c}\text { Largest } \\
\text { Tide } \\
(\mathrm{m})\end{array}$ \\
\hline Karachi & $\begin{array}{c}6 \mathrm{hr} \\
13 \mathrm{~min}\end{array}$ & $\begin{array}{c}6 \mathrm{hr} \\
11 \mathrm{~min}\end{array}$ & 1.60 & 3.63 \\
\hline $\begin{array}{c}\text { Port Qasim } \\
\text { (Entr.) }\end{array}$ & $\begin{array}{c}6 \mathrm{hr} \\
19 \mathrm{~min}\end{array}$ & $\begin{array}{c}6 \mathrm{hr} \\
06 \mathrm{~min}\end{array}$ & 1.70 & 3.93 \\
\hline $\begin{array}{c}\text { Port Qasim } \\
\text { (Pipri) }\end{array}$ & $\begin{array}{c}6 \mathrm{hr} \\
42 \mathrm{~min}\end{array}$ & $\begin{array}{c}6 \mathrm{hr} \\
42 \mathrm{~min}\end{array}$ & 1.85 & 4.50 \\
\hline Ormara & $\begin{array}{c}6 \mathrm{hr} \\
06 \mathrm{~min}\end{array}$ & $\begin{array}{c}6 \mathrm{hr} \\
18 \mathrm{~min}\end{array}$ & 1.35 & 2.98 \\
\hline Pasni & $\begin{array}{c}6 \mathrm{hr} \\
07 \mathrm{~min}\end{array}$ & $\begin{array}{c}6 \mathrm{hr} \\
18 \mathrm{~min}\end{array}$ & 1.55 & 3.08 \\
\hline Gwadar & $\begin{array}{c}6 \mathrm{hr} \\
07 \mathrm{~min}\end{array}$ & $\begin{array}{c}6 \mathrm{hr} \\
17 \mathrm{~min}\end{array}$ & 1.35 & 3.04 \\
\hline Hajambro Creek & $\begin{array}{c}6 \mathrm{hr} \\
22 \mathrm{~min}\end{array}$ & $\begin{array}{c}6 \mathrm{hr} \\
03 \mathrm{~min}\end{array}$ & 1.74 & 3.44 \\
& \multicolumn{2}{|c}{} & \\
\hline
\end{tabular}

Electricity can also be generated by thermal heat which is stored between the layers of water of the sea. On an average direct radiation of 3.338 to $3.936 \mathrm{KWh} / \mathrm{m}^{2}$ per day is absorbed by Pakistan Sea, considering the area of Pakistan offshore territory total of $1015 \mathrm{GWh}$ per day is absorbed by water [10]. This energy can also be harnessed to full fill the daily demand of electricity in Pakistan.

\section{Bioenergy}

Bioenergy is the form of renewable energy which is obtained from organic matter and can be used for many purposes such as generation of electrical energy. Organic matter can be of many types such as bagasse a residue of sugar making process, municipal or any other waste.

In the sugar industry when sugar cane is being processed the residual material is known as bagasse which is a source of 
energy for many purposes. Around 3-7 kg of bagasse is required to generate $1 \mathrm{KWh}$ of electricity [11]. Pakistan is fifth largest producer of sugar cane so a lot of bagasse is available in the country for the utilization as renewable source of energy. There are around 86 sugar-based mills in Pakistan processing about 48 million tons of sugar cane every year yielding about 14.4 million tons of bagasse which can be used to generate $1400 \mathrm{MW}$ of power [12]. One other thing which is important while talking about this process that sugar canes are processed in winter season when generation through hydropower is less so this can add up with the nation grid to meet the daily demand. Currently around twenty-seven power plants are operational having a generating capacity of 550.6 MW while 14 numbers of power plants are under construction or proposed with the generation capacity of $480.9 \mathrm{MW}$ [3]. Still there has been a lot of power which can be produced from this method.

In Pakistan a total of 55000 tons of waste is produced in the urban areas daily. This waste can be used for generation of electricity by the process of burning and the by-products in the process can also be treated so that the environment remains clean. Considering the amount of waste nearly $3.33 \mathrm{MW}$ of energy can be produced. Waste from the cattle and poultry farms can also be used or the generation of electricity. This waste can be changed into biogas and this gas can be used as a source. According to a survey only in Karachi a single poultry farm generates 15 tons of chicken litter per years which can generate electrical energy up to 43MW daily which can not only full fill the need of that particular project but can also electrify the nearby area.

Livestock dung can also be used for the generation of electricity, according to the economic survey of Pakistan there are about 69.6 million numbers of livestock (cows and buffalos) on an average a single animal has dung of $15 \mathrm{Kg} /$ day so the total dung of around 1044 million kilograms is produced per day [14]. Considering only the fifty percent of the available dung which is 522 million kilograms, biogas of 26.1 million $\mathrm{m}^{3}$ can be generated per day. A single $\mathrm{m}^{3}$ of biogas can generate electrical energy of $6 \mathrm{KWh}$ so 159.6 million KWh of energy can be obtained from the livestock per day or around $6650 \mathrm{MW}$ per year [15].

\section{Geothermal Energy}

Geothermal energy is the energy stored in the earth in the form of heat. Temperature in the core of energy is as high as $5000^{\circ} \mathrm{C}$ and can be accessed in the form of hot water from the spring or can be obtained by throwing water on the hot rock and making steam out of it.

Geothermal sources of energy on all over the earth are 80 times more than the oil resources. Most of the geothermal resources lie along the seismic best and this belt passes through Pakistan. These resources are not restricted only one of the province of Pakistan but are present in all around the country. Government of Pakistan has included the geothermal resources of energy in the policy of development of renewable energy for the generation of electric power. There are reservoirs of hot magmatic water in Chagai volcanic arc in
Baluchistan province which is around 150 degrees centigrade hot. There are some reservoirs of hot water (80-170 degree centigrade) in Sindh. There are also 300 dried oil and gas wells which can be used for obtaining geothermal energy. According to the research 100,000 MW of energy can be obtained from geothermal sources in Pakistan [16].

\section{E. Solar Energy}

Solar energy is the transformation of sun light into electrical power either directly by using photovoltaic cells or indirectly by using concentrated solar power. Photovoltaic cells convert sun light directly to electricity by using photovoltaic phenomena while in the concentrated solar power method sun light is directed on lenses and then passed through a narrow channel then the heat energy is used for the purpose of generating electric energy [17].

Electrical energy from the solar is obtained by mean of solar thermal or by photovoltaic cells. Currently Pakistan has solar plants in Kashmir, Punjab, Sindh and Baluchistan. Pakistan is in action to build biggest solar power plants in Cholistan desert. Quaid-e-Azam Solar power plant will be fully operational in 2017 and can generate up to $1 \mathrm{GW}$ of power [18]. Figure 1 shows solar potential of different areas of Pakistan. It is obvious from the figure that the area in region of Sindh and Baluchistan receive most amount of energy. On an average Pakistan receives 19MJ of solar energy per square meter. Average daily insulation rate $-5.3 \mathrm{kWh} / \mathrm{m}^{2}$. Sun shines for $3000 \mathrm{hrs}$ per annum in south-western province of Baluchistan. Jacobabad receives $2,142 \mathrm{kWh}$ of solar irradiation $/ \mathrm{m}^{2} /$ year.

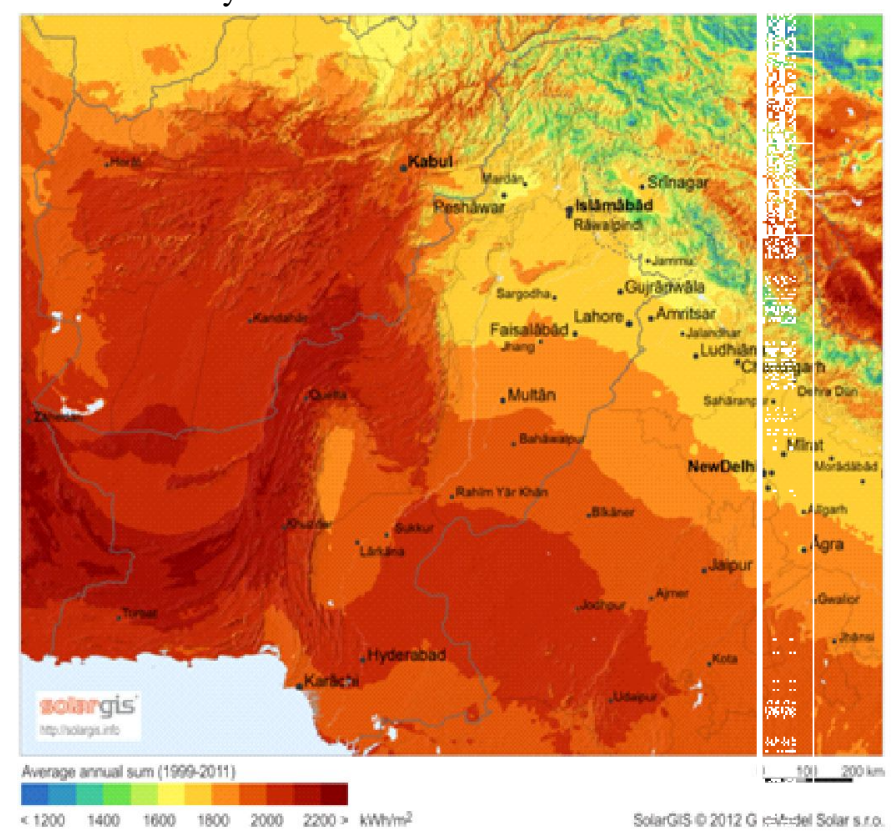

Figure 5: Solar potential of Pakistan.

Pakistan set a target to add approximately $10 \mathrm{GW}$ of renewable capacity by 2030 in addition to replacing $5 \%$ diesel with biodiesel by 2015 and $10 \%$ by 2025 . Pakistan is an exceptionally sunny country. If $0.25 \%$ of Baluchistan (about $0.1 \%$ of Pakistan) is covered with solar panels with an 
efficiency of just $20 \%$, enough electricity would be generated to cover all of Pakistani demand. Only two solar power plants are installed in Pakistan which are currently generating $180 \mathrm{MV}$ of energy. In the near future around 17 new solar power plants are under construction with the total generating capacity of 1096MV [3].

Table 3: Purposed solar power plants

\begin{tabular}{|c|c|c|}
\hline Station & Location & $\begin{array}{c}\text { Capacit } \\
\text { y (MW) }\end{array}$ \\
\hline Scatec Solar Project & Sindh & 150 \\
\hline HENDS Energy Pvt. Ltd. & Sindh & 50 \\
\hline Helios Power Pvt. Ltd. & Sindh & 50 \\
\hline Oursons Pakistan Ltd. & Sindh & 50 \\
\hline Conergy Solar Project & Sindh & 50 \\
\hline DACC LLC Solar & Sindh & 50 \\
\hline Wah Industries Ltd. Solar & Taxila & 1 \\
\hline Tech Access Solar & Punjab & 10 \\
\hline Solar Energy Pakistan Ltd. & Thatta & 35 \\
\hline Roshan Power Solar & Kasur & 10 \\
\hline Harappa Power Solar & Sahiwal & 18 \\
\hline First Solar & Punjab & 2 \\
\hline CWE Solar & Bahawalpu & 50 \\
& r & \\
\hline Bakhsh Energy Solar & Lodhran & 20 \\
\hline Inter-tech Kuwait Investment & Quetta & 500 \\
\hline Authority & & \\
\hline Conergy Solar Project & Bahawalpu \\
r & 50 \\
\hline
\end{tabular}

\section{F. Wind Energy}

Figure 6 shows the histogram for the year 2003, representing the Annual wind speed data probability density function (hourly averaged taken at 61 meters height). As it is abundantly clear that the random variable is in discrete form [19].

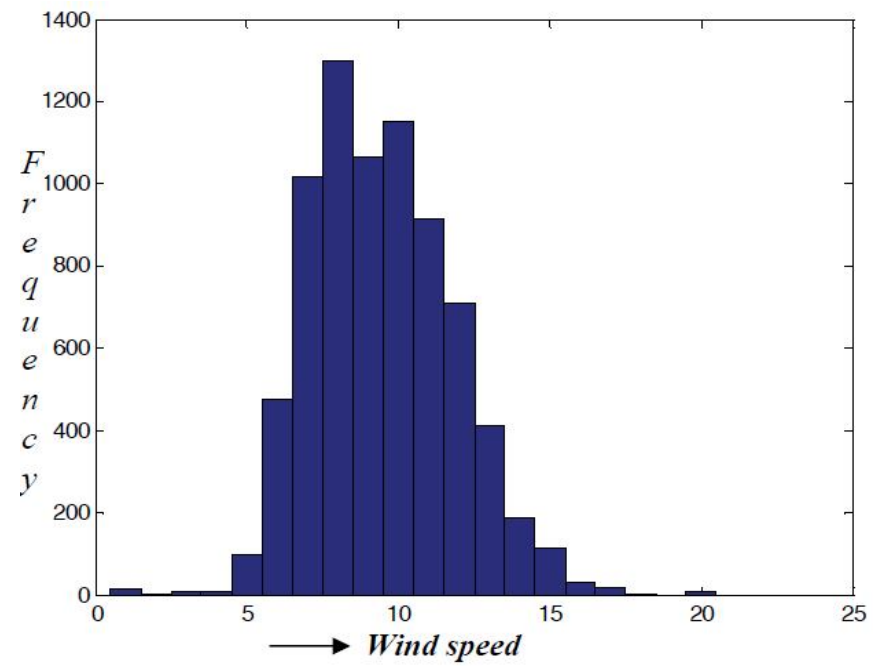

Figure 6: Annual wind speed data (hourly averaged taken at 61 meters height) histogram for the year 2003 .

The average annual wind speed in Karachi, Pakistan, is found to be following Weibull distribution (1) where $\mathrm{k}$ and $\mathrm{c}$ are the shape and scale parameters respectively [21]. Hence, in our case, this distribution is perfect for administering simulation on various wind turbines' specification/parameters [20].

$$
f(x)=\left[\frac{k}{\varepsilon}\right]\left[\frac{b}{\varepsilon}\right]^{k-1} e^{-\left[\frac{y}{\varepsilon}\right]^{k}}
$$

$$
v \geq 0, k>1, \varepsilon>0
$$

The data obtained is rather crude and raw in nature Matlab algorithm is used to draw a continuous Weibull probability distribution function, adjusting the shape factor $k$ and scale factor $c$, until it matches the original histogram. In our particular case a value of 3.5 for $k$ and, 9 for $c$ was witnessed to best suit our original discrete histogram.

\section{G. Hybrid and Related Technologies}

Hybrid technology is the one in which renewable energy generation system is connected to other type of generation system. This is one of the most important factors in setting up the power system as renewable resources of energy cannot be used as a standalone unit. The fuel of the renewable system cannot be controlled so it is necessary to have a system whose fuel can be controlled to have the desired power generation. Thus both types of power systems are integrated to have a required power generation level.

\section{SIMULATION AND RESULTS}

First using [22] Matlab, a cumulative distribution function of Weibull Distribution is generated using programming command (2) where $k$, the shape factor is 3.5 and, $c$, the scale factor is 9. Then using a built-in Matlab function we create the continuous probability density function using (3). Figure 7 shows the plot of continuous Weibull probability density function.

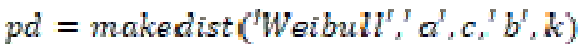

$$
\begin{aligned}
& y=p d f\left(p d, x_{\text {nolueg }}\right) \text {; } \\
& \operatorname{disp}(y) \text { : }
\end{aligned}
$$

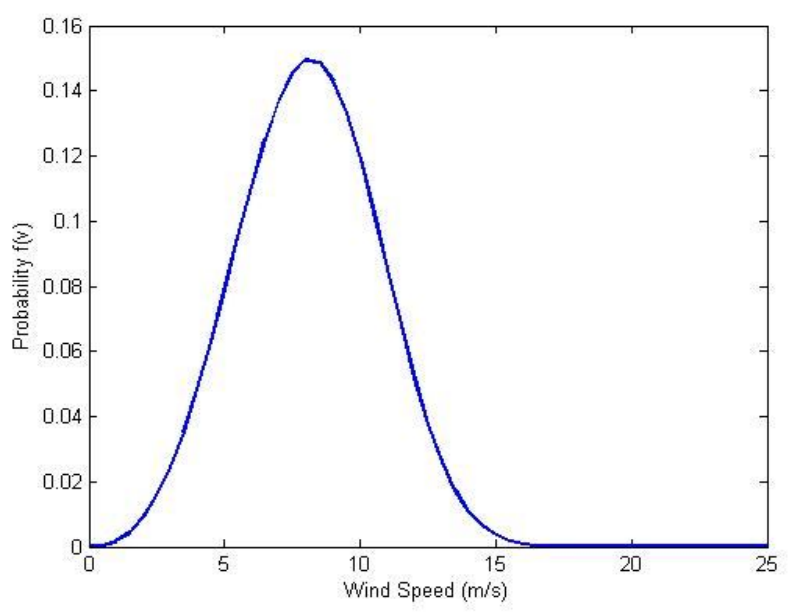

Figure 7: Weibull probability density function (refined) 
Abubakar Siddique et al., International Journal of Emerging Trends in Engineering Research, 9(4), April 2021, 508 - 514

Finally, using (4) 25 discrete yet refined values are extracted on the Matlab command terminal. This data will be populated in spreadsheet to perform statistical calculations.

Column No. 2 of Tables 4, 5, 6 and 7 analyzing four different Wind Turbines, namely Bonus 300 33/4, NEG Micon 1000/60, Vestas 600/42 and Whisper 0.9/2.13, has been populated with the corresponding Wind Turbine Efficiency data. Whereas Column No. 3 of Tables 4, 5, 6 and 7 is populated with the discrete data taken from the Matlab command panel as a result of executing (4). Cumulative calculations are programmed in the spreadsheet to acquire the average Wind Speed, the average value of cube of Wind Speed and, the total annual energy generated.

Table 4: Bonus 300 33/4

\begin{tabular}{|c|c|c|c|c|c|c|}
\hline $\begin{array}{l}\text { Wind } \\
\text { speed } \\
(\mathrm{m} / \mathrm{s}) \\
\end{array}$ & $\begin{array}{l}\text { Power } \\
(\mathrm{KW})\end{array}$ & $\begin{array}{c}\text { Prob. } \\
\text { f(v) }\end{array}$ & $\begin{array}{c}\mathrm{Hrs} / \mathbf{y r} \\
\text { at vi }\end{array}$ & $\begin{array}{c}\text { vi } * \mathbf{f}(\mathbf{v}) \\
\text { meter/sec } \\
\text { ond }\end{array}$ & $(\mathbf{v i})^{\wedge} \mathbf{3} * \mathbf{f}(\mathbf{v})$ & $\begin{array}{c}\begin{array}{c}\text { Energy } \\
(\mathrm{kWh} / \mathrm{yr})\end{array} \\
\end{array}$ \\
\hline 0 & 0 & 0 & 0 & 0 & 0 & 0 \\
\hline 1 & 0 & 0.0016 & 14.02 & 0.0016 & 0.0016 & 0 \\
\hline 2 & 0 & 0.009 & 78.84 & 0.018 & 0.072 & 0 \\
\hline 3 & 4 & 0.0244 & 213.7 & 0.0732 & 0.6588 & 854.976 \\
\hline 4 & 15 & 0.0483 & 423.1 & 0.1932 & 3.0912 & 6346.62 \\
\hline 5 & 32 & 0.0787 & 689.4 & 0.3935 & 9.8375 & 22061.18 \\
\hline 6 & 52 & 0.1108 & 970.6 & 0.6648 & 23.9328 & 50471.61 \\
\hline 7 & 87 & 0.137 & 1200 & 0.959 & 46.991 & 104410.4 \\
\hline 8 & 129 & 0.1494 & 1309 & 1.1952 & 76.4928 & 168827.9 \\
\hline 9 & 172 & 0.1431 & 1254 & 1.2879 & 104.3199 & 215611.6 \\
\hline 10 & 212 & 0.1192 & 1044 & 1.192 & 119.2 & 221368.7 \\
\hline 11 & 251 & 0.0853 & 747.2 & 0.9383 & 113.534 & 187554.2 \\
\hline 12 & 281 & 0.0517 & 452.9 & 0.6204 & 89.3376 & 127262.6 \\
\hline 13 & 297 & 0.0261 & 228.6 & 0.3393 & 57.3417 & 67904.89 \\
\hline 14 & 305 & 0.0107 & 93.73 & 0.1498 & 29.3608 & 28588.26 \\
\hline 15 & 300 & 0.0035 & 30.66 & 0.0525 & 11.8125 & 9198 \\
\hline 16 & 281 & 0.0009 & 7.884 & 0.0144 & 3.6864 & 2215.404 \\
\hline 17 & 271 & 0.0002 & 1.752 & 0.0034 & 0.9826 & 474.792 \\
\hline 18 & 259 & 0 & 0 & 0 & 0 & 0 \\
\hline 19 & 255 & 0 & 0 & 0 & 0 & 0 \\
\hline 20 & 253 & 0 & 0 & 0 & 0 & 0 \\
\hline 21 & 254 & 0 & 0 & 0 & 0 & 0 \\
\hline 22 & 255 & 0 & 0 & 0 & 0 & 0 \\
\hline 23 & 256 & 0 & 0 & 0 & 0 & 0 \\
\hline 24 & 257 & 0 & 0 & 0 & 0 & 0 \\
\hline 25 & 258 & 0 & 0 & 0 & 0 & 0 \\
\hline 26 & 0 & 0 & 0 & 0 & 0 & 0 \\
\hline Total & & 0.9999 & 8759 & 8.0965 & 690.653 & 1213151. \\
\hline
\end{tabular}

Table 5: NEG Micon 1000/60

\begin{tabular}{|c|c|c|c|c|c|c|}
\hline $\begin{array}{l}\text { Wind } \\
\text { speed } \\
(\mathrm{m} / \mathrm{s})\end{array}$ & $\begin{array}{l}\text { Power } \\
(\mathrm{KW})\end{array}$ & $\begin{array}{l}\text { Prob. } \\
\mathrm{f}(\mathrm{v})\end{array}$ & $\begin{array}{c}\mathrm{Hrs} / \mathrm{yr} \text { at } \\
\text { vi }\end{array}$ & $\begin{array}{c}\text { vi } * f(v) \\
\text { meter/seco } \\
\text { nd }\end{array}$ & $\begin{array}{c}(\mathrm{vi})^{\wedge} 3 * \\
\mathrm{f}(\mathrm{v})\end{array}$ & $\begin{array}{c}\text { Energy } \\
(\mathrm{kWh} / \mathrm{yr})\end{array}$ \\
\hline 0 & 0 & 0 & 0 & 0 & 0 & 0 \\
\hline 1 & 0 & 0.0016 & 14.02 & 0.0016 & 0.0016 & 0 \\
\hline 2 & 0 & 0.009 & 78.84 & 0.018 & 0.072 & 0 \\
\hline 3 & 0 & 0.0244 & 213.7 & 0.0732 & 0.6588 & 0 \\
\hline 4 & 33 & 0.0483 & 423.1 & 0.1932 & 3.0912 & 13962.5 \\
\hline 5 & 86 & 0.0787 & 689.4 & 0.3935 & 9.8375 & 59289.4 \\
\hline 6 & 150 & 0.1108 & 970.6 & 0.6648 & 23.9328 & 145591 \\
\hline 7 & 248 & 0.137 & 1200 & 0.959 & 46.991 & 297629 \\
\hline 8 & 385 & 0.1494 & 1309 & 1.1952 & 76.4928 & 503866 \\
\hline 9 & 535 & 0.1431 & 1254 & 1.2879 & 104.3199 & 670652 \\
\hline 10 & 670 & 0.1192 & 1044 & 1.192 & 119.2 & 699608 \\
\hline 11 & 780 & 0.0853 & 747.2 & 0.9383 & 113.5343 & 582837 \\
\hline 12 & 864 & 0.0517 & 452.9 & 0.6204 & 89.3376 & 391298 \\
\hline 13 & 924 & 0.0261 & 228.6 & 0.3393 & 57.3417 & 211259 \\
\hline 14 & 964 & 0.0107 & 93.73 & 0.1498 & 29.3608 & 90357.6 \\
\hline 15 & 989 & 0.0035 & 30.66 & 0.0525 & 11.8125 & 30322.7 \\
\hline 16 & 1000 & 0.0009 & 7.884 & 0.0144 & 3.6864 & 7884 \\
\hline 17 & 998 & 0.0002 & 1.752 & 0.0034 & 0.9826 & 1748.49 \\
\hline 18 & 987 & 0 & 0 & 0 & 0 & 0 \\
\hline 19 & 968 & 0 & 0 & 0 & 0 & 0 \\
\hline 20 & 944 & 0 & 0 & 0 & 0 & 0 \\
\hline
\end{tabular}

\begin{tabular}{|c|c|c|c|c|c|c|}
\hline 21 & 917 & 0 & 0 & 0 & 0 & 0 \\
\hline 22 & 889 & 0 & 0 & 0 & 0 & 0 \\
\hline 23 & 863 & 0 & 0 & 0 & 0 & 0 \\
\hline 24 & 840 & 0 & 0 & 0 & 0 & 0 \\
\hline 25 & 822 & 0 & 0 & 0 & 0 & 0 \\
\hline 26 & 0 & 0 & 0 & 0 & 0 & 0 \\
\hline Total & & 0.9999 & 8759 & 8.0965 & 690.6535 & $\begin{array}{c}3706309 . \\
6\end{array}$ \\
\hline
\end{tabular}

Table 6: Vestas 600/42

\begin{tabular}{|c|c|c|c|c|c|c|}
\hline $\begin{array}{l}\text { Wind } \\
\text { speed } \\
(\mathrm{m} / \mathrm{s})\end{array}$ & $\begin{array}{l}\text { Power } \\
\text { (KW) }\end{array}$ & $\begin{array}{r}\text { Prob. } \\
\text { f(v) }\end{array}$ & $\begin{array}{c}\mathrm{Hrs} / \mathbf{y r} \\
\text { at vi }\end{array}$ & $\begin{array}{c}\mathbf{v i} * \mathbf{f}(\mathbf{v}) \\
\text { meter/sec } \\
\text { ond }\end{array}$ & $\begin{array}{c}(\mathbf{v i})^{\wedge} 3^{*} \\
\mathbf{f}(\mathbf{v})\end{array}$ & $\begin{array}{c}\text { Energy } \\
(\mathbf{k W h} / \mathbf{y r})\end{array}$ \\
\hline 0 & 0 & 0 & 0 & 0 & 0 & 0 \\
\hline 1 & 0 & 0.0016 & 14.02 & 0.0016 & 0.0016 & 0 \\
\hline 2 & 0 & 0.009 & 78.84 & 0.018 & 0.072 & 0 \\
\hline 3 & 0 & 0.0244 & 213.7 & 0.0732 & 0.6588 & 0 \\
\hline 4 & 0 & 0.0483 & 423.1 & 0.1932 & 3.0912 & 0 \\
\hline 5 & 22 & 0.0787 & 689.4 & 0.3935 & 9.8375 & $\begin{array}{c}15167.06 \\
4\end{array}$ \\
\hline 6 & 65 & 0.1108 & 970.6 & 0.6648 & 23.9328 & 63089.52 \\
\hline 7 & 120 & 0.137 & 1200 & 0.959 & 46.991 & 144014.4 \\
\hline 8 & 188 & 0.1494 & 1309 & 1.1952 & 76.4928 & $\begin{array}{c}246043.8 \\
7\end{array}$ \\
\hline 9 & 268 & 0.1431 & 1254 & 1.2879 & 104.3199 & $\begin{array}{c}335953.0 \\
1\end{array}$ \\
\hline 10 & 356 & 0.1192 & 1044 & 1.192 & 119.2 & $\begin{array}{c}371732.3 \\
5\end{array}$ \\
\hline 11 & 440 & 0.0853 & 747.2 & 0.9383 & 113.5343 & $\begin{array}{c}328780.3 \\
2\end{array}$ \\
\hline 12 & 510 & 0.0517 & 452.9 & 0.6204 & 89.3376 & $\begin{array}{c}230974.9 \\
2\end{array}$ \\
\hline 13 & 556 & 0.0261 & 228.6 & 0.3393 & 57.3417 & $\begin{array}{c}127121.6 \\
2\end{array}$ \\
\hline 14 & 582 & 0.0107 & 93.73 & 0.1498 & 29.3608 & $\begin{array}{c}54552.02 \\
4\end{array}$ \\
\hline 15 & 594 & 0.0035 & 30.66 & 0.0525 & 11.8125 & 18212.04 \\
\hline 16 & 598 & 0.0009 & 7.884 & 0.0144 & 3.6864 & 4714.632 \\
\hline 17 & 600 & 0.0002 & 1.752 & 0.0034 & 0.9826 & 1051.2 \\
\hline 18 & 600 & 0 & 0 & 0 & 0 & 0 \\
\hline 19 & 600 & 0 & 0 & 0 & 0 & 0 \\
\hline 20 & 600 & 0 & 0 & 0 & 0 & 0 \\
\hline 21 & 600 & 0 & 0 & 0 & 0 & 0 \\
\hline 22 & 600 & 0 & 0 & 0 & 0 & 0 \\
\hline 23 & 600 & 0 & 0 & 0 & 0 & 0 \\
\hline 24 & 600 & 0 & 0 & 0 & 0 & 0 \\
\hline 25 & 600 & 0 & 0 & 0 & 0 & 0 \\
\hline 26 & 0 & 0 & 0 & 0 & 0 & 0 \\
\hline Total & & 0.9999 & 8759 & 8.0965 & 690.6535 & 1941407 \\
\hline
\end{tabular}

Table 7: Whisper 0.9/2.13

\begin{tabular}{|c|c|c|c|c|c|c|}
\hline $\begin{array}{l}\text { Wind } \\
\text { speed } \\
(\mathrm{m} / \mathrm{s})\end{array}$ & $\begin{array}{l}\text { Power } \\
\text { (KW) }\end{array}$ & $\begin{array}{c}\text { Prob. } \\
\text { f(v) }\end{array}$ & $\begin{array}{c}\mathrm{Hrs} / \mathbf{y r} \\
\text { at vi }\end{array}$ & $\begin{array}{c}\mathbf{v i} * \mathbf{f}(\mathbf{v}) \\
\text { meter/sec } \\
\text { ond } \\
\end{array}$ & $\begin{array}{c}(\mathbf{v i})^{\wedge} \mathbf{3}^{*} \\
\mathbf{f}(\mathbf{v})\end{array}$ & $\begin{array}{c}\text { Energy } \\
(\mathrm{kWh} / \mathrm{yr})\end{array}$ \\
\hline 0 & 0 & 0 & 0 & 0 & 0 & 0 \\
\hline 1 & 0 & 0.0016 & 14.02 & 0.0016 & 0.0016 & 0 \\
\hline 2 & 0 & 0.009 & 78.84 & 0.018 & 0.072 & 0 \\
\hline 3 & 0.03 & 0.0244 & 213.7 & 0.0732 & 0.6588 & 6.41232 \\
\hline 4 & 0.08 & 0.0483 & 423.1 & 0.1932 & 3.0912 & 33.84864 \\
\hline 5 & 0.17 & 0.0787 & 689.4 & 0.3935 & 9.8375 & $\begin{array}{c}117.2000 \\
4\end{array}$ \\
\hline 6 & 0.25 & 0.1108 & 970.6 & 0.6648 & 23.9328 & 242.652 \\
\hline 7 & 0.35 & 0.137 & 1200 & 0.959 & 46.991 & 420.042 \\
\hline 8 & 0.45 & 0.1494 & 1309 & 1.1952 & 76.4928 & 588.9348 \\
\hline 9 & 0.62 & 0.1431 & 1254 & 1.2879 & 104.3199 & $\begin{array}{c}777.2047 \\
2\end{array}$ \\
\hline 10 & 0.78 & 0.1192 & 1044 & 1.192 & 119.2 & $\begin{array}{c}814.4697 \\
6\end{array}$ \\
\hline 11 & 0.9 & 0.0853 & 747.2 & 0.9383 & 113.5343 & 672.5052 \\
\hline 12 & 1.02 & 0.0517 & 452.9 & 0.6204 & 89.3376 & 461.9498 \\
\hline
\end{tabular}


Abubakar Siddique et al., International Journal of Emerging Trends in Engineering Research, 9(4), April 2021, 508 - 514

\begin{tabular}{|c|c|c|c|c|c|c|}
\hline & & & & & & 4 \\
\hline 13 & 1.05 & 0.0261 & 228.6 & 0.3393 & 57.3417 & 240.0678 \\
\hline & & & & & & 101.2305 \\
14 & 1.08 & 0.0107 & 93.73 & 0.1498 & 29.3608 & 6 \\
\hline 15 & 1.04 & 0.0035 & 30.66 & 0.0525 & 11.8125 & 31.8864 \\
\hline 16 & 1.01 & 0.0009 & 7.884 & 0.0144 & 3.6864 & 7.96284 \\
\hline 17 & 1 & 0.0002 & 1.752 & 0.0034 & 0.9826 & 1.752 \\
\hline 18 & 0.99 & 0 & 0 & 0 & 0 & 0 \\
\hline 19 & 0.97 & 0 & 0 & 0 & 0 & 0 \\
\hline 20 & 0.95 & 0 & 0 & 0 & 0 & 0 \\
\hline 21 & 0 & 0 & 0 & 0 & 0 & 0 \\
\hline 22 & 0 & 0 & 0 & 0 & 0 & 0 \\
\hline 23 & 0 & 0 & 0 & 0 & 0 & 0 \\
\hline 24 & 0 & 0 & 0 & 0 & 0 & 0 \\
\hline 25 & 0 & 0 & 0 & 0 & 0 & 0 \\
\hline 26 & 0 & 0 & 0 & 0 & 0 & 0 \\
\hline & & & & & & 4518.118 \\
Total & & 0.9999 & 8759 & 8.0965 & 690.6535 & 9 \\
\hline
\end{tabular}

\section{CONCLUSION}

Pakistan has huge renewable energy resources and with proper planning and investment, energy deficit as well as pollution could be brought low, considerably. Currently there has been some development in the field of renewable resources but still there are many fields to explore. Section VI confirms that Micon 1000/60 wind turbine has produced a whopping energy of $3706309.6\left(\mathrm{kWh} . \mathrm{yr}^{-1}\right)$ for the year 2003, hence the ideal investment.

\section{REFERENCES}

[1] Ntdc.com.pk. (2016). National Transmission And Despatch Company Limited (NTDC) Pakistan. [online] Available at: http://www.ntdc.com.pk/WapdaPowerHistory.php [Accessed 4 Dec. 2016].

[2] The Express Tribune. (2016). Pakistan's energy security - The Express Tribune. [online] Available at: http://tribune.com.pk/story/655573/pakistans-energy-security/ [Accessed 7 Dec. 2016].

[3] "List of power stations in Pakistan", En.wikipedia.org, 2016. [Accessed: 7- Dec- 2016].

[4] "Small hydro-power units for remote villages", DAWN.COM, $2016 . \quad$ [Online]. Available: http://www.dawn.com/news/207750. [Accessed: 7- Dec2016].

[5] Hassan, M.U., "Development of renewable energy technologies in Pakistan - an overview", Pakistan Council of Renewable Energy Technologies, Ministry of Science \& Technology, pp. 1-3, 2002.

[6] Emec.org.uk. (2016). Marine Energy : EMEC: European Marine Energy Centre. Available at: http://www.emec.org.uk/marine-energy/ [Accessed 11 Dec. 2016].

[7] Australian Sustainable Business - The Switch Report. (2016). I Want To Love Wave Power. Really I Do. But.... [online] Available

at: http://www.theswitchreport.com.au/tech/want-love-wave-pow er-really-stack/ [Accessed 11 Dec. 2016].

[8] DAWN.COM. (2016). Pakistan seabed territory grows by 50,000 square kilometers. Available at: http://www.dawn.com/news/1170986 [Accessed 11 Dec. 2016].
[9] Slideshare.net. (2016). Ocean Based Power and its Huge Potential as a Renewable Energy Source. [Accessed 11 Dec. 2016].

[10] Pmd.gov.pk. (2016). Pakistan Meteorological Department PMD. [online] Available at: http://www.pmd.gov.pk/ [Accessed 11 Dec. 2016].

[11] S. C. Bhattacharayya and D. N. Q. Thang, "The cogeneration potential

of the sugar indudstry in Vietnam," Oganization of Petroleum Exporting

Countries, 2004

[12] A. Saeed, "Prospects of Bagasse as a feasible bio-fuel for electricity generation in Pakistan - A realistic approach," 2015 Power Generation System and Renewable Energy Technologies (PGSRET), Islamabad, 2015, pp. 1-4.

[13] N. Zaigham and Z. Nayyer, "Prospect of renewable energy sources in Paksitan", Proceedings of COMSATS Conference2004 on Renewable Energy Technologies \& Sustainable Develoment, 2005.

[14] J. Ahmad, "Economic Survey of Pakistan \& Livestock Sector (2013-2014)", Veterinary Hub, 2016. [Online]. Available: http://www.veterinaryhub.com/economic-survey-of-pakistan-li vestock-sector-2013-2014/. [Accessed: 19- Dec- 2016].

[15] "Electricity Generation from Biogas - energypedia.info", Energypedia.info, 2016. [Online]. Available: https://energypedia.info/wiki/Electricity_Generation_from_Bi ogas. [Accessed: 19- Dec- 2016].

[16] T. Paper, "Pak geothermal energy resources have potential to generate 100,000MW power: Research", Thenews.com.pk, 2016. [Online]. Available: https://www.thenews.com.pk/print/107384-Pak-geothermal-en ergy-resources-have-potential-to-generate-100000MW-powerResearch\#. [Accessed: 31- Dec- 2016].

[17] "Solar power", En.wikipedia.org, 2016. [Online]. Available: https://en.wikipedia.org/wiki/Solar_power\#Concentrated_sola r_power. [Accessed: 31- Dec- 2016].

[18] "Solar power in Pakistan", En.wikipedia.org, 2016. [Online]. Available:

https://en.wikipedia.org/wiki/Solar_power_in_Pakistan. [Accessed: 31- Dec- 2016].

[19] M.A. Hussain, Shaheen Abbas, M.R.K. Ansari, Asma Zaffar and Bulbul Jan, "Wind Speed Analysis of Some Coastal Areas near Karachi," in Proc. of the Pakistan Academy of Sciences 51 (1): 83-91, 2014

[20] Keyhani, Ali, "Design of Smart Power Grid Renewable Energy Systems." Hoboken, N.J: Wiley, 2011, pp. 339-345.

[21] Gilbert M. Masters, "Renewable and Efficient Electric Power Systems, New Jersey, Wiley, 2004, pp. 343-343.

[22] Fatemeh Shakhsi Salim, "Hypothesis Testing for three main Reliability Models," M.S. thesis, Dept. Statistics, University of Regina, Saskatchewan, Canada, 2015. 